\title{
LA PRIMERA PERSONA, EL AMOR Y LA PERSISTENCIA DE LAS PREGUNTAS EN EL TELÓN DE AZÚCAR, de CAMila GuZMán Urzúa
}

\begin{abstract}
Anabella Castro Avelleyra *
Resumo: Entendendo a experiência dos anos noventa como uma pulsão que promove a busca de novas perspectivas sobre a atualidade (Dipaola, 2012), o artigo reflete sobre o lugar do autobiográfico e o performativo, o subjetivo e o individual na construção e desconstrução da Revolução e da sociedade cubana desde o Período Especial no documentário El telón de azúcar (2005), de Camila Guzman Urzúa.

Palavras-chave: cinema cubano, Período Especial, documentário performativo.

Resumen: Comprendiendo a la experiencia de los años noventa como una pulsión que promueve la búsqueda de nuevas miradas sobre la actualidad (Dipaola, 2012), el artículo intenta reflexionar sobre el lugar de lo autobiográfico y lo performativo, lo subjetivo y lo individual en la construcción y deconstrucción de la Revolución y la sociedad cubana a partir del Período Especial en el documental El telón de azúcar (2005), de Camila Guzmán Urzúa.

Palabras clave: cine cubano, Período Especial, documental performativo.

Abstract: Understanding the experience of the nineties as a drive that promotes the search for new perspectives on today (Dipaola, 2012), the article reflects on the place of the autobiographical and the performative, the subjective and the individual in the construction and deconstruction of the Revolution and Cuban society since the Special Period in the documentary El telón de azúcar (2005), by Camila Guzman Urzúa.

Keywords: Cuban cinema, Special Period, performative documentary.

Résumé: Pour comprendre l'expérience des années quatre-vingt dix comme stimulation qui favorise la recherche de nouvelles perspectives aujourd'hui (Dipaola, 2012), l'article se penche sur la place de l'autobiographique et du performatif, du subjectif et et de l'individu dans la construction et la déconstruction de la Révolution et de la société cubaine de la Période spéciale dans le documentaire El telón de azúcar (2005), de Camila Guzman Urzúa.
\end{abstract}

Mots-clés: cinéma cubain, Période Spéciale, documentaire performatif.

\footnotetext{
* Doutoranda. Universidad de Buenos Aires, Faculdad de Filosofía y Letras, Instituto de História del Arte Argentino y Latinoamericano. 1181, Buenos Aires, Argentina.

E-mail: anabella.castro.a@gmail.com
}

Submissão do artigo: 26 de junho de 2015. Notificação de aceitação: 07 de setembro de 2015. 
Así que los noventa con algo de los ochenta, el rebote tal vez, es lo que nos constituye. Romina Paula, Agosto.

\section{Introducción}

Camila Guzmán Urzúa, la directora del documental El telón de azúcar (2005), nació en Chile en 1971. El golpe de Estado contra el gobierno de Salvador Allende hizo que su familia (su padre es el cineasta Patricio Guzmán, director de La batalla de Chile) se exiliara en Cuba. Así, Camila llegó a La Habana a los dos años de edad y pasó allí su infancia y adolescencia. Luego de finalizados sus estudios, viajó a Europa para pasar tiempo con su padre, quien había abandonado el país poco después de su arribo. Años más tarde, a mediados de la década del 2000, Camila regresó a Cuba a realizar un documental que podría calificarse como autobiográfico ${ }^{1}$, en el que vuelve sobre los recuerdos y los espacios de sus primeros años interrogándolos desde una actualidad fuertemente marcada por los estragos del Período Especial.

En ese contrapunto entre el ayer y el hoy, entre la próspera Cuba de los ochenta y el país desolado por el Período Especial, y también entre la infancia y la adultez se desarrolla El telón de azúcar, una indagación política y social, pero sobre todo personal. Es desde allí - desde lo propio, lo íntimo, el yo- que se construye - y deconstruye - un entramado amplio que propone más preguntas sinceras que respuestas definitivas en torno a la Revolución y la sociedad cubana.

La propuesta del trabajo es realizar una lectura del filme a partir de las reflexiones de Esteban Dipaola (2012) en su libro Todo el resto. Estética

1 Subjetivo, performativo, en primera persona, ensayístico, son otras posibles clasificaciones. 
y pulsión de los años '90, traspolando su análisis de la cultura argentina a la cubana. También intentaremos pensar el régimen de verdad que propone el documental a partir de las ideas desarrolladas por Alain Badiou (2012) en Elogio del amor. Nos proponemos explicar por qué consideramos que el film se encuadra dentro de los documentales autobiográficos, tomando como guías los pensamientos de Esteban Dipaola (2012), Ana Amado (2009) y Pablo Piedras (2009). Eric Selbin (2012) también nos permitirá arribar a estas conclusiones a partir del concepto de storyteller.

\section{Los noventa en Cuba y su proyección en el cine reciente}

En su relato, Camila parte de la premisa de que los ochenta fueron "años dorados". Su voz estipula al comienzo del film: "pertenecimos a la generación de cubanos nacidos y criados en los años dorados de la Revolución”. Realiza aquí una triple inscripción: 1) ella, aunque nacida en Chile y actualmente residente europea, se considera cubana y se inscribe como tal en el relato; 2) hay un yo que opera como narrador; ${ }^{2}$ y finalmente, 3) establece a los ochenta como los años dorados de la Revolución, afirmación que podría cuestionarse desde la Historia "dura", dado que ya en esa década el campo socialista europeo se encontraba en crisis (Perestroika, Glasnost) y eso tenía una repercusión negativa sobre Cuba. Habiendo establecido que la directora se inscribe como un yo a cargo de quien estará la narración, resulta posible comprender el concepto de "años dorados" más allá de lo político-económico-social, o sea, centrándonos no tanto en la

\footnotetext{
${ }^{2}$ Si bien la frase citada refiere a un "nosotros", anteriormente, en las palabras iniciales del film, Camila se inscribe claramente como el "yo" narrador. Luego de mostrarnos imágenes de pioneros en la escuela Camila relata: Así crecí yo. Usé ese mismo uniforme y también dije que sería como el Che. Eso fue hace más de veinte años y recuerdo que Cuba era como un paraíso. Un lugar sin preocupaciones, sin angustia, sin violencia. Aquí el dinero no tenía valor, lo material no tenía importancia y no existía ni el desempleo ni la religión. En esta isla calurosa la solidaridad reinaba en todas partes. Todos nos sentíamos iguales y en las calles no había ni publicidad ni apuro. (Aparece aquí el insert de una foto de Camila en 1977, en la que se lee "Recuerdo de pre escolar"). Recuerdo que fui muy feliz.
} 
Historia sino en la historia, comprendida esa catalogación así entonces desde la visión subjetiva de la niñez $z^{3}$. Más allá de esto, es innegable que la economía cubana en la década del ochenta era aún lo suficientemente próspera como para garantizar la satisfacción de las necesidades de todos sus ciudadanos. Redundan en este sentido en el film las declaraciones en torno a la abundancia de comida y la desestimación del dinero, que no era considerado como algo esencial o ni siquiera necesario. Esta bienaventuranza se debía en gran medida a los estrechos vínculos del país con la Unión Soviética, con quien mantenía casi todas sus relaciones de intercambio comercial, planteadas en un sentido altamente beneficioso para Cuba. La caída del muro de Berlín en 1989 y posteriormente la disolución de la Unión Soviética, en 1991, conllevaron al ingreso del país en lo que se denominó el Período Especial en Tiempos de Paz. La crisis económica subsiguiente alcanzó una magnitud desconocida en Cuba desde el triunfo de la Revolución ${ }^{4}$. El gobierno tomó entonces una serie de medidas económicas y políticas que buscaban ajustar la economía a la nueva realidad. Esta reforma se proponía la reinserción de Cuba en el mercado capitalista mundial, el mejoramiento del consumo y el aseguramiento de las necesidades básicas de la población, garantizando a su vez la supervivencia de las conquistas revolucionarias y el modelo político socialista (Álvarez Arce, 2006). Las nuevas medidas económicas incluyeron el fomento del turismo, la libre circulación de monedas extranjeras y el ingreso de capitales foráneos en algunas áreas de la economía como, por ejemplo, la producción

\footnotetext{
${ }^{3}$ En palabras de Rainer María Rilke, "La única patria que tiene el hombre es su infancia". Es inevitable tener esto en consideración a la hora de analizar El telón de azúcar.

${ }^{4}$ En su libro Raúl Castro, estratega de la defensa revolucionaria de Cuba, Hal Klepak (2010) enumera las siguientes cifras: una retracción de la economía de entre el 35 y el $50 \%$ entre 1989 y 1993; una profunda disminución de las exportaciones, debido a que la Unión Soviética absorbía el 63\% de la producción de azúcar, el 73\% del níquel, el 95\% de los cítricos y el $100 \%$ de los componentes eléctricos; una importante disminución de las importaciones, ya que la URSS era proveedora, en el campo de productos importados, del $63 \%$ de los alimentos, el $80 \%$ de maquinarias y equipos y el $74 \%$ de bienes manufacturados. Así, señala Klepak, Cuba perdió el $80 \%$ de su poder de compra en el exterior (p. 107).
} 
cinematográfica. Esto se debió a que la inversión estatal se vio reducida en múltiples sectores, de los cuales el cine no fue ajeno. El dinero asignado a la producción cinematográfica se redujo de modo brusco, mermando significativamente el número de films producidos por año y convirtiendo al régimen de coproducción con otros países en la única alternativa para la realización de películas. De este modo, el cine cubano comenzó a establecer fuertes vínculos transnacionales con otras cinematografías. A partir del 2000, el ingreso en la era digital favoreció un incremento en el número de films realizados y una significativa diversificación de la producción cinematográfica, que dejó de ser dependiente del Instituto Cubano del Arte e Industria Cinematográficos (ICAIC). En este tipo de producciones se enmarca El telón de azúcar, realizada de modo independiente al Instituto, con la financiación de diversas instituciones de distintas nacionalidades. ${ }^{5}$

Llegados a este punto, cabe pensar en las reflexiones de Ulrich Beck (2006) en torno a la individualización para comprender los cambios a los que se vio expuesta (de modo brusco) la sociedad cubana. El autor habla de “un tipo de 'cambio de forma' o de 'cambio categorial' en la relación entre individuo y sociedad" (2006: 209), al que refiere como un nuevo modo de sociabilización. Beck habla de una triple individualización:

disolución de las precedentes formas sociales históricas y de los vínculos en el sentido de dependencias en la subsistencia y dominio tradicionales ("dimensión de liberación"); pérdida de seguridades tradicionales en relación al saber hacer, creencias y normas orientativas ("dimensión de desencanto"), y un nuevo tipo de cohesión social ("dimensión de control o de integración”). (ídem: 210).

\footnotetext{
5 Los títulos del film nombran a las siguientes empresas productoras e instituciones auspiciantes: Luz Films (Francia), Paraíso Production Diffusion (Francia), Televisión Española, Groupe de Recherches et Essais Cinématographiques París (G.R.E.C.), Escuela Internacional de Cine y Televisión de San Antonio de los Baños (Cuba), Cine en Construcción Toulouse Donastía, San Sebastián.
} 
Esto parece ser lo ocurrido en Cuba con posterioridad al inicio de la crisis del Período Especial y, en tal sentido, se hace presente en El telón de azúcar. La primera dimensión señalada por Beck se aprecia en los cambios que se producen en los individuos en torno a su posibilidad de dependencia del Estado, ya sea en cuanto a sus garantías laborales (con el ingreso de la divisa en el sistema económico cubano los salarios estatales en moneda nacional no alcanzan para la supervivencia), como al resto de las garantías sociales (merma en los productos entregados a partir de la libreta de abastecimiento, por ejemplo). En el primer caso, de acuerdo a lo que señala una de las entrevistadas en el documental, la dependencia parecería simplemente correrse de lugar, ya que asegura que si no fuera por las remesas que le envía su hermano desde el exterior, no podría vivir de su salario. Respecto a lo segundo, una niña muestra su libreta, en la que muchos troqueles permanecen intactos ya que, señala su madre, ninguno de esos artículos aún se entregaron, tras lo cual recuerda todo lo que les era facilitado profusamente con anterioridad. La segunda dimensión se expresa en los cambios acaecidos en la sociedad y su vinculación con diversas áreas, una de las cuales es la profesional. La posición que otorgaba la posesión de un título, el desempeño de un oficio o profesión, se ve rearticulada en función de las nuevas lógicas de funcionamiento económico, en las que, como manifiesta uno de los entrevistados en el documental, se aspira a ser botones de un hotel por la posibilidad de ingresos en divisas que ello implica, mayores a los que se obtendrían desempeñando una profesión tradicional. El mismo entrevistado sostiene que esa falta de deseo por estudiar y desarrollarse en una profesión por parte de los jóvenes está dada por aquello en lo que los trabajos en Cuba han devenido: hacer una labor mecánica, sin mucho empeño, en la que no se entrega todo ya que la energía debe ponerse en alguna otra labor que permita "resolver", hacerse de la divisa necesaria para subsistir. La tercera dimensión deriva de las dos anteriores (como puede apreciarse, las tres están íntimamente 
interrelacionadas) y tiene que ver con una reestructuración de la cohesión social, que adquiere nuevas y cambiantes características. Una de las ex compañeras de escuela de Camila comienza su relato sosteniendo, ¿Qué cambió? Todo. La gente. La sociedad. La forma de uno poder obtener el dinero para vivir. No sé... todo cambió. Después de que comenzó el Período Especial todo cambió. Todo es diferente. Fue salir de la felicidad para entrar en la infelicidad. Fue difícil. El nuevo tipo de cohesión social, lejana y ya casi ajena a la de comienzos de la Revolución, contempla y justifica actitudes individualistas y no solidarias, como los pequeños robos efectuados por quienes trabajan en fábricas o bodegas, vistos como "necesarios" para la propia subsistencia.

\section{La fuga, la deriva, los traslados}

En su libro Todo el resto. Estética y pulsión de los años '90, Esteban Dipaola (2012) analiza el lugar que ocupa la década del noventa en la producción cultural posterior. A pesar de que su análisis se centra en Argentina, las reflexiones son en gran medida extrapolables a lo sucedido en Cuba. Dipaola plantea que "algo nos pasó en los noventa y no deja de pasarnos" (2012: 7, cursivas en el original). Esa reflexión, aplicada por el autor a los años de neoliberalismo salvaje, puede comprenderse también pensando en los años del Período Especial en Cuba y la crisis, no sólo económica sino de valores, que conllevó. “¿Se fueron los noventa?”, se pregunta. Y responde, "(s)i los noventa remiten a una temporalidad es porque dejaron marcas" (ídem: 10). Sin dudas, los noventa en Cuba no se fueron en el sentido de que dejaron marcas profundas en la sociedad, aún apreciables. Estas marcas son fundantes de la narración en el film de Camila. Los noventa articulan el relato de la década anterior, ideal e idealizada, y de la posterior, acuciante y controvertida. La caída del muro de Berlín, la disolución de la Unión Soviética y la inevitable crisis bautizada 
como Período Especial son las marcas lacerantes que propician la reflexión sobre el pasado proyectándolo hacia el presente. Dipaola plantea la posibilidad de "pensar los noventa bajo la figura de la temporalidad y, con ellos, pensar los años en fuga". Agrega que esa noción de fuga "ha sido una constante en la literatura y la cinematografía naciente por aquellos años. Las películas de lo que se conoció como Nuevo Cine Argentino, recurrían permanentemente a la estética de una experiencia de la fuga, de la deriva, de los traslados" (ídem: 13,14). La fuga aparece también en el cine cubano producido a partir de los noventa de múltiples formas. Por un lado, la fuga como opción primordial: fugarse al exterior, emigrar, ya sea a través de la búsqueda del otorgamiento de una visa, por el matrimonio con un extranjero, o huyendo de modo ilegal. Como sucede con un elevado porcentaje de los films realizados con posterioridad al ingreso en el Período Espacial, la temática de la emigración atraviesa El telón de azúcar. Cada una de las voces que contribuye a la construcción del relato está matizada por la emigración: la de un hermano o hermana, la de los padres, la de amigos o incluso la propia. La deriva también, personajes que deambulan por la ciudad, sin rumbo aparente, cooptados por la incertidumbre característica de esos tiempos. En El telón de azúcar, específicamente, la manifestación política parece haberse convertido de marcha firme y convencida en simple deriva, deambular. Los traslados aparecen como doble problemática, por un lado vinculados a la fuga y a la deriva, pero también como alegato de la crisis del transporte aparece el traslado como deseo problemático. La fuga, la deriva y el traslado también pueden apreciarse en las inquietudes estéticas y formales que manifiestan los films del período. Los sentidos y las identidades se interpretan y construyen como en constitución permanente; ya no se trata de sentidos e identidades fijas, estáticas, fosilizadas, cerradas, sino fluidas, inasibles, que escapan, en movimiento constante. Creemos que es posible establecer un cierto paralelismo, a la vez, entre el Nuevo Cine Argentino y el cine producido a 
partir del Período Especial en Cuba no sólo por estas constantes apreciables en ambas cinematografías y por la incidencia de los contextos políticos, económicos y sociales, sino también a partir de otro factor propiciador del surgimiento de estos nuevos cines. Si en el nacimiento del Nuevo Cine Argentino tuvo que ver el capital profesional surgido de la Fundación Universidad del Cine (FUC), lo mismo puede pensarse en la renovación del cine cubano a partir de las primeras generaciones de egresados de la Escuela Internacional de Cine y Televisión (EICTV) de San Antonio de los Baños y de la Facultad de Arte de los Medios de Comunicación Audiovisual (FAMCA) del Instituto Superior de Arte (ISA) y la renovación que esos nuevos realizadores inyectaron en el panorama del cine hasta entonces reinante, producido en el marco de formación del ICAIC. ${ }^{6}$ En este sentido, Joel del Río (2011) también señala en su artículo "Fermentos genéricos en el cine joven del siglo XXI" la importancia de cuatro eventos en el desarrollo del cine cubano de la última década y media: el Festival Internacional del Nuevo Cine Latinoamericano, el Festival Internacional Santiago Álvarez in Memoriam, el Festival Internacional de Cine Pobre y la Muestra Joven organizada por el ICAIC. Hace hincapié sobre todo en esta última y destaca, a partir de ella, una reanimación en el cine documental, que al momento se encontraba estancado al interior del Instituto. Entre los principales problemas que evidenciaba el documental institucional señala “el exceso de apología y exégesis, la confusión de los realizadores respecto al reportaje televisivo de ocasión, la violación del punto de vista y de los

\footnotetext{
${ }^{6}$ En una primera etapa de desarrollo de la cinematografía cubana aún no existían en el país escuelas de cine, por lo cual la formación se daba de modo "artesanal" al interior del Instituto. Los fundadores habían realizado su formación en el exterior (Tomás Gutiérrez Alea y Julio García Espinosa habían pasado por el Centro Sperimentale di Cinematografía, en Italia) y, en el quehacer cotidiano, bajo su ala se iba formando el relevo. Los jóvenes interesados en participar de la realización cinematográfica se acercaban al ICAIC y comenzaban trabajando como asistentes de producción. Luego pasaban a producción, asistencias de dirección, dirección de sus propios documentales, en un camino que, eventualmente, alrededor de los cuarenta años de edad, los "graduaba" como directores de largometrajes de ficción.
} 
principios dramatúrgicos elementales, exceso de didactismo y de convenciones, y el uso pedestre y poco creativo del archivo o de la entrevista" (2011: 405, 406). Frente a esto, los nuevos documentalistas aparecen como comprometidos en la reflexión sobre aspectos problemáticos de la realidad social, generando una polémica en torno a esos temas que propicie la concientización y el debate social. El autor señala la importancia en estos films de la dimensión emotiva, que no va en detrimento del rigor y la profundidad, algo apreciable en El telón de azúcar. En torno a estos documentales Del Río también sostiene valores aplicables a la película de Camila Guzmán Urzúa, entre los que destaca "problematizar el entorno, complejizar la existencia, plantar un espejo revelador ante lo que es poco conocido y terminar revelando circunstancias muchas veces dolorosas, discutibles, ásperas, invariablemente situadas más allá de la mera propaganda o de la divulgación concebida para apaciguar la digestión de los conformistas" (ídem: 406).

En esta línea se distinguen una serie de documentales contemporáneos al de Guzmán Urzúa, que se le emparentan por distintas cuestiones tanto formales como temáticas. Habana abierta, dirigido por Arturo Sotto y Jorge Perugorría en 2003, registra el retorno del grupo musical homónimo tras su triunfo en España. Algunos de los integrantes de la banda dan su testimonio también en El telón de azúcar, donde aparece el registro de esa presentación en vivo que marcó su triunfal bautismo en los escenarios cubanos. La canción que Camila elige hacernos escuchar es, no casualmente, "Divino guion", cuya lírica reza "La vida es un divino guión (...) / Quedó bonito pero se destiñe / Ya no es lo mismo que cuando éramos fiñes / Pioneros por el comunismo / Ilusión de cosmonautas / Todas las ratas se van tras la flauta / José Martí fijó la pauta / El elefante tiene cuatro patas / Y una memoria que te aplasta / Yo no me fui, yo me alejé un poquito / Desde más lejos se oye más bonito". En lo que respecta a lo formal, el recurso a la primera persona así como la reflexión sobre la repercusión del 
pasado en el presente puede apreciarse en documentales como Las colmenas (Alejandro Ramírez Anderson, 2007) y The Illusion (Susana Barriga, 2009). El primero trabaja sobre la experiencia personal del director en un proyecto a través del cual un grupo de hijos de guerrilleros guatemaltecos fueron protegidos del contexto que los rodeaba siendo llevados a Cuba, donde crecieron. Aunque el formato del documental es el clásico de entrevistas, al comienzo el director se dirige a cámara inscribiéndose como yo narrador al señalar que él formó parte del proyecto y que la historia que se narrará es, también, su historia. En un tono más intimista y experimental, la película de Susana Barriga registra la búsqueda y el (des)encuentro con un padre autoexiliado y paranoico.

Esteban Dipaola vuelve sobre el concepto de fuga analizando la obra teatral de Mariano Pensotti El pasado es un animal grotesco. Sostiene que se trata del retrato de

una generación que tuvo que vivir la experiencia de heredar un pasado que no le corresponde ni pertenece y afrontar una proyección en donde nada parece indicar qué se hallará sobre el camino en ese tránsito hacia adelante. Apenas un relato de los noventa, entonces, se presenta justamente en esa condición: fugar de lo que no se quiere hacia lo que no se sabe. (Dipaola, 2012: 36).

Los cambios a los que se ve enfrentada la generación de Camila (pero más aún, como señala uno de los entrevistados, los cambios más profundos a los que se ven enfrentadas las generaciones criadas en el Período Especial, a quienes verdaderamente el pasado ya parece no corresponder ni pertenecerles en absoluto) genera una fuga desde algo que no se quiere (esa realidad actual) hacia lo que no se sabe (el futuro incierto, el exterior desconocido). La emigración, como hemos señalado, se retrata en el film de múltiples formas. El recuerdo de una ex compañera que ya no está y que sólo puede hacerse presente a través de un video que la hermana muestra a 
Camila, donde se ve a su pequeña hija contando a cámara del uno al diez, primero en inglés y recién después en castellano. O los padres milicianos y alfabetizadores de un joven que eligió quedarse, aunque ellos se fueron, desilusionados por el resultado de todo, tenían otra idea de lo que iba a ser su vida con la Revolución, y con el Período Especial ellos pensaron que todo lo que habían hecho por esto no había servido para nada, como sostiene el hijo. O el compañero que regresa de visita y ve todo con una mirada externa. Y esa suerte de epílogo final, en el que junto con él Camila también ya una emigrada que regresa de visita- nombra a todos los amigos que se fueron. Es una lista larga, interminable, que se oye en off mientras la cámara muestra un parque con juegos infantiles vacíos, abandonados. Es la puesta en escena de esa larga y dolorosa fuga "de lo que no se quiere hacia lo que no se sabe", que parece haber comprendido a toda una generación.

\section{El despojo, el desamparo}

Dipaola propone como conceptos característicos de la década del noventa en Argentina al despojo y al desamparo y elije a la cinematografía de Raúl Perrone para dar cuenta de cómo esto aparece de modo concreto,

las calles del conurbano bonaerense están ahora (des)pobladas por edificios abandonados a medio construir, fábricas cerradas, negocios oscuros y de persianas semibajas; y entre todo ello, hacen su aparición jóvenes desinteresados por los valores y las prácticas de antaño: no buscan trabajo o escapan a las posibles maneras de conseguirlo, y en cualquier caso siempre se trata de trabajos precarios y sin proyección, yacen tirados en plazas fumando o tomando cerveza, miran televisión, deambulan, etc. (Dipaola, 2012: 19).

En El telón de azúcar lo que nos es mostrado es el contrapunto entre los edificios en pleno funcionamiento en la década del ochenta (a través de 
inserts de fotografías) y su estado de derruimiento actual. En una escena, Camila y dos de sus amigas recuerdan el campamento de pioneros Tarará. La puesta en escena de ese recuerdo supone la contraposición entre el ayer y el hoy: mientras vemos imágenes de un espacio completamente abandonado, que a partir de algunas desgastadas pintadas en la pared podemos inferir que estaba dedicado a la infancia, en off escuchamos las voces de las jóvenes narrando historias felices de su época de esplendor. Vemos la Cuba que fue y se nos insta a imaginar el país que podría haber sido, para finalmente mostrarnos el país que es, éste en el que se convirtió realmente. Mientras las imágenes del actual estado de Tarará continúan, la voz de Camila relata

Hoy, las ruinas de nuestros recuerdos cohabitan con los nuevos empresarios extranjeros y con algunas víctimas de Chernobyl que llegan todavía a recibir tratamiento médico. Ya nada es lo que era, siento que mi país de infancia ha desaparecido. Sólo quedan las consignas y las viejas estructuras de aquel sueño que entonces tenía sentido y que yo me creí.

En la primera parte de esta reflexión (y en el contrapunto con las imágenes que la acompañan) se pone de manifiesto la realidad contradictoria de la contemporaneidad cubana. Las ruinas de la prosperidad revolucionaria, los emprendimientos turísticos financiados con capitales foráneos y el sostenimiento de baluartes característicos de la Revolución, como la solidaridad, el internacionalismo y la medicina "de punta" cohabitan en esa nueva sociedad a la que aún no le cabe otra etiqueta que la de quien atraviesa un "Período Especial". En el discurso de los entrevistados (todos compañeros de escuela de Camila, amigos de la infancia) se pone de manifiesto el cambio en la escala de valores de la juventud. Uno de ellos, quien actualmente reside en el exterior, sostiene, comparando a su generación con la actual: 
es una realidad que te forma con seguridad en ti mismo, con capacidad sobre todo. Y tú lo notas. Cuando tú te sientes que tú compites, ese nivel de competencia te lo da tu educación anterior, tu realidad anterior que fue aquí. Eso fue una suerte realmente, sobre todo para nuestra generación, la que viene no sé. Nosotros éramos los forjadores del futuro, no jodas, eso te da tremenda responsabilidad y tremenda confianza también. Y yo me lo sigo creyendo, aunque esté donde esté.

Escuchamos entonces la voz de Camila en off, que le pregunta cuál cree que es la diferencia con la juventud de hoy. El entrevistado prosigue:

pienso que si estudiar no vale nada porque al final lo que quieres es ser portero de un hotel o trabajar en una tienda o algo de eso, entonces al estudiar no valer nada, no estudias, y al no estudiar, no tienes referentes, y al no tener referentes ni leer ni oír buena música ni ver buen cine, pues nada, te quedas parado en la esquina del club esperando al extranjero de tu vida. Ya el plan cambió. El plan es qué vas a hacer cuando salgas de aquí.

Sostiene Dipaola que surge entonces la "sensación de que no hay nada o no hay mucho para hacer", abundando en la cinematografía de esos años imágenes que daban cuenta de "la abulia, la apatía, un imaginario del cansancio y del desgaste, cierta soledad y desolación" (ídem: 20). En la cinematografía cubana del período, así como en el film que nos compete, esto también es apreciable aunque, a su vez, hay siempre una pulsión vital que hace que los personajes nunca se detengan del todo, nunca acaben de darse por vencidos, siempre intenten "inventar", "resolver", para seguir adelante. En el caso de los entrevistados en El telón de azúcar parece haber algo de su formación en esos idílicos -e idealizados- años ochenta que les da una fortaleza -que por momentos parecería ser más bien nostálgica- para continuar. Al mismo tiempo, hay un cierto desamparo vivenciado por una generación que nació en la década del setenta, en el éxtasis de una lucha revolucionaria que atravesaba toda Latinoamérica (se puede ver en el documental, por ejemplo, en el retorno sobre la figura de Salvador Allende 
en Chile), y a la que los cambios políticos producidos con posterioridad y reafirmados sobre todo en la década del noventa la vuelve, de algún modo, huérfana. Se genera así una situación peculiar que el film construye como una contradicción entre teoría y práctica. Las imágenes actuales de los niños y los adolescentes, con las enseñanzas escolares y los himnos que recuperan las históricas y míticas figuras de Camilo Cienfuegos, Ernesto Che Guevera, Conrado Benítez y José Martí, así como las consignas revolucionarias que Guzmán Urzúa nos muestra a partir de carteles en las calles, chocan con las declaraciones de los entrevistados que dan cuenta de la profunda crisis económica y de valores, que conlleva la naturalización de pequeños robos para subsistir. En los jóvenes que asisten a las marchas, toman clases de “preparación militar" con armas de cartón o realizan trabajo voluntario ("obligatorio", acota en un momento Camila, intensificando la contradicción), parecen perpetuarse prácticas propias de la generación que presta su testimonio en el film, pero que se realizan ahora sin un sentido real, sin saber por qué. Así, la teoría revolucionaria y la práctica del “inventar" coexisten en una contradicción velada, no siempre manifiesta. Ponerla de manifiesto parece ser parte de la propuesta de Guzmán Urzúa en el film. De este modo, una escena muestra imágenes del Museo de la Revolución: las figuras hechas en cera de Camilo y el Che, el rígido traje de un cosmonauta cubano, encerrado en un cubo de cristal. La Revolución parece encontrarse estática, detenida, pieza de museo. A través de un corte la directora procede a mostrarnos luego, como contrapunto, el Malecón, el mar agitado, vital, que rompe contra esa pared de piedra que intenta contenerlo y no lo consigue, ya que él estalla y se vierte sobre la ciudad. 


\section{... y no deja de pasarnos}

La experiencia de los noventa, de acuerdo a Esteban Dipaola, se convierte en una pulsión que promueve de modo permanente la búsqueda de una nueva mirada.

Si es posible argumentar que los noventa es algo que nos pasó y no deja de pasarnos, se debe (...) a esa pulsión que nos indica siempre la necesidad y búsqueda de una nueva mirada, porque justamente lo que aparece allí es que la mirada sobre los noventa no es ya nunca una mirada sobre el pasado, sino sobre nuestra actualidad, sobre nuestra forma de intervenir hoy en la experiencia de nuestras vidas y en sus resignificaciones. (Dipaola, 2012: 22).

Algo de esto se aprecia en las miradas que sobre los noventa realiza el cine cubano. La mirada de Camila en El telón de azúcar es sobre la actualidad y "la forma de intervenir hoy en la experiencia de nuestras vidas". Aquellos años se resignifican, resignificando a su vez el presente del relato. Más que mirar hacia atrás, la búsqueda de Camila consiste en una reflexión sobre la actualidad.

Continúa planteando Dipaola al respecto que "(s)e trata de una insistencia, una pulsión que arrastra experiencias para componer momentos del presente que no pueden prescindir de esa especie de lazo íntimo con la memoria y los vestigios de esa década del noventa" (ídem: 39). El telón de azúcar es, sobre todo, una indagación sobre el presente, que vuelve sobre los noventa porque eso es lo que "nos pasó y no deja de pasarnos", eso que nos insta a buscar una nueva mirada que nos permita comprender nuestra actualidad. Por eso, creería, ya no estamos ante el reinado del documental expositivo, la Historia, la sentencia, la afirmación unívoca, "la" Verdad, sino que se produjo el ingreso en el documental autobiográfico, la historia, la interrogación, las preguntas que se ramifican e, intentaremos proponer a 
continuación, un procedimiento de verdad a partir del amor, una verdad del Dos.

\section{Camila y Cuba: el amor y la verdad}

Alain Badiou (2012) sostiene en Elogio del amor que éste es

un "procedimiento de verdad" (...), una experiencia en la que se construye cierto tipo de verdad. Esta verdad es sencillamente la verdad del Dos. La verdad de la diferencia como tal. Pienso que el amor (...) que acepte justamente esta experiencia del mundo desde el punto de vista de la diferencia produce a su manera una verdad nueva acerca de la diferencia. (Badiou, 2012: 43).

Partiendo de estas reflexiones cabe pensar si acaso no es amor lo que se da entre Camila Guzmán Urzúa y Cuba, y si en esa experiencia no se construye un cierto tipo de verdad, que tiene que ver con la diferencia. Una doble diferencia, podríamos pensar. Por un lado, la diferencia entre Camila y Cuba, pero también la diferencia entre esa Cuba en la que Camila creció y ésta a la que regresa. Dos Camilas y dos Cubas. La verdad del dos y de la diferencia como tal. Podemos pensar así en dos momentos del amor, dos momentos de la verdad y dos momentos de la diferencia en su primera llegada a Cuba y en el retorno.

Sostiene también Alain Badiou que "el amor comienza por el carácter absolutamente contingente y azaroso del encuentro. (...) Pero el azar debe, en un momento, fijarse. Debe, justamente, comenzar una duración" (ídem: 45). Aquí, siguiendo la lógica que hemos implementado, podríamos pensar en el azar del comienzo de este amor, lo azaroso por lo cual Camila llega a Cuba a los dos años de edad. Y cómo luego ese azar se fija y comienza una duración que incluso la lleva a volver para interrogar ese amor, esa relación, esa diferencia, esa verdad. Patricio, el padre de 
Camila, abandona Cuba al poco tiempo de su llegada, pero ella se queda con su madre, fijando el azar, comenzando la duración de este amor.

Continúa Badiou sus reflexiones sosteniendo que "de lo que fue un azar voy a sacar otra cosa. Voy a sacar de él una duración, una obstinación, un compromiso, una fidelidad" (ídem: 47). Leo “obstinación” y pienso inmediatamente en la película del padre de Camila, Chile, la memoria obstinada (Patricio Guzmán, 1997), ese retorno sobre La batalla de Chile años después, esa vuelta atrás sobre la memoria y me pregunto si no hay allí un mecanismo similar al de El telón de azúcar, una obstinación en la memoria y, al mismo tiempo, su actualización. Un compromiso y una fidelidad con el amor. Un ejercicio de producción de verdad permanente.

Concluye Badiou diciendo:

Hay puntos, pruebas, tentaciones, nuevas apariciones y, cada vez, es necesario volver a interpretar la "escena del Dos", encontrar los términos de una nueva declaración. Declarado al inicio, el amor también debe ser "re-declarado". Es por esto que el amor es también el origen de las crisis existenciales violentas. Como todo procedimiento de verdad. Desde este punto de vista, además, es chocante la vecindad que existe entre el amor y la política. (ídem: 53).

Podríamos pensar en la partida de Camila, en el derrotero del Período Especial y sus coletazos como esos "puntos, pruebas, tentaciones" y "nuevas apariciones" de las que habla Badiou. El retorno de Camila y su ejercicio al realizar el documental es síntoma de esa necesidad de "volver a interpretar la escena del Dos”. Hay aquí una re-declaración del amor, una crisis existencial violenta y, por supuesto, una vecindad entre el amor y la política.

Nos parece válido pensar, a partir de estas reflexiones, en que hay una cierta calidad particular de verdad en la propuesta de Camila Guzmán Urzúa, el tipo de verdad que surge del amor, de la escena del Dos y de sus permanentes reinterpretaciones. 


\section{Camila, la cuentacuentos}

Eric Selbin (2012) plantea en El poder del relato. Revolución, rebelión, resistencia que los pueblos cuentan historias, y que son éstas las que los definen como pueblos. "Creamos, entendemos y dirigimos el mundo a través de las historias que contamos" (p. 17). Agrega posteriormente que "quiénes somos, qué somos, es inseparable de las historias que contamos. Lo cual, finalmente, equivale a decir que las historias son todo, y que todo, de una forma u otra, es una historia" (ídem: 17). Se puede comprender así un cambio en las historias que el pueblo cubano narra. Si hasta el Período Especial se contaba un determinado tipo de historias (podemos pensar, por ejemplo, en un cine de características más bien épicas, en un cine histórico), y a partir de aquel momento empiezan a contarse historias de otro tipo, tiene que ver también con una reestructuración del quién y qué somos. Hay una retroalimentación entre este cuestionamiento, los procesos de (re)constitución identitaria ${ }^{7}$ y las historias que se cuentan.

En el tipo de historias narradas a partir del Período Especial, a diferencia de lo ocurrido con anterioridad, las preguntas que se realizan adquieren una importancia superior a las respuestas dadas. Esto, el privilegio de las preguntas en el cine reciente por sobre el hincapié en las respuestas que existía en el cine anterior, es algo que se aprecia al comparar los filmes de los setenta con los de los noventa y las décadas posteriores. Si el cine político de los setenta encontraba su mecanismo en la afirmación de sentencias definitivas, el cine reciente, y sobre todo el de características

\footnotetext{
${ }^{7}$ La hipótesis de trabajo de mi tesis de posgrado en curso parte de la premisa de una reconfiguración identitaria a partir del ingreso en el Período Especial. Se considera que ésta es producto de diversos factores, uno de los cuales sería el intento desde la oficialidad de crear una cubanidad más amplia e inclusiva en el afán de contrarrestar los posibles efectos negativos que la crisis pudiera tener en la gobernabilidad y lo social. Esto conduce a la visibilización e inclusión de sectores anteriormente discriminados, como los religiosos y los emigrados. Esto, sumado al compulsivo ingreso en regímenes de coproducción, se manifiesta a su vez en la construcción cinematográfica de la identidad, que se empieza a considerar como más porosa, híbrida y móvil.
} 
autobiográficas, centra su lógica en la presentación de preguntas. Y son estas las que adquieren verdadera relevancia por sobre cualquier tipo de respuesta (siempre parcial, fragmentada) que pudiera encontrarse. A algo de esto parece referirse Selbin cuando señala que "las respuestas, con sus distintas calidades y sus diversos grados de satisfacción, parecen ir y venir; lo que sobrevive son las preguntas" (ídem: 17).

De acuerdo a Selbin,

"Historia" es el término comúnmente utilizado para rotular a nuestro depósito de conocimiento; y en otras épocas estaba constituida por las tradiciones populares, los relatos y los cuentos. La Historia, tradicionalmente, narraba historias que eran una combinación de realidad y ficción. Esto, en la euforia de la Ilustración y particularmente a los ojos del racionalismo del siglo XIX, fue súbitamente considerado un horror. Mucho esfuerzo fue puesto en la idea de que los historiadores eran artesanos (...) que lidiaban únicamente con "hechos". Mientras que los narradores eran libres de inventar lo que quisieran, los historiadores debían ceñirse a la Verdad, una convicción orientada a obtener el estatuto de "ciencia" que ha dominado a las sociales hasta el día de hoy. (ídem: 18, 19).

Una nota del traductor señala que el término utilizado en el original de Selbin es storyteller, al que el traductor prefiere expresar como "narrador", por las posibles implicaciones desmerecedoras que la traducción “cuentacuentos" pudiera conllevar. Me parece interesante la posibilidad de pensar a Camila como una cuentacuentos, no sólo por la libertad de inventar con la que narra, sino por la frescura de un relato que no intenta ceñirse a la Verdad y, así y todo, da cuenta de una verdad concreta, tal como expusimos anteriormente.

\section{El documentalismo del yo}

Consideramos que El telón de azúcar es, por sus características, un documental autobiográfico. En este sentido, Esteban Dipaola sostiene que 
la autobiografía no se constituye como documentación de la época, sino como interpretación y síntoma de ella. Es decir, no es ese registro autobiográfico algo exterior respecto a lo narrado o al relato, sino que se configura y disemina en sus trayectorias internas. Lo biográfico se expresa como una experiencia y, como tal, se muestra en el despliegue temporal con todas sus vicisitudes y dislocaciones -incluso con sus propias ficciones- y no como racconto lineal de una historia. (Dipaola, 2012: 27).

Como ya hemos expresado, creemos que el filme de Camila Guzmán Urzúa constituye una interpretación de la época, una mirada y, en función de las reflexiones acerca de la proyección de los noventa en el cine reciente, también un síntoma de esa época. El film no se propone como documento, sino como indagación personal e interpretación de la historia reciente de un país y su proyección en el presente. Así, la narración de Camila va y viene, entre épocas y espacios, voces que se multiplican y que también se quiebran o no pueden escucharse, entre los niños del hoy, que aprenden y repiten lecciones y prácticas de antaño y los jóvenes adultos que vuelven sobre esos niños que una vez fueron y que fundan a esos seres que hoy afrontan y confrontan un presente ríspido y desolador.

Pablo Piedras (2009) retoma las reflexiones de Antonio Weinrichter en torno al modo performativo del documental, sosteniendo que, en éste, "hay un trastorno observable de la experiencia del director - de su cuerpo, de sus disposiciones psicológicas y de sus actitudes-, que desvía nuestra atención de la cualidad referencial del documental". El propósito de tal desvío es, de acuerdo al autor, "subrayar los aspectos subjetivos de un discurso clásicamente objetivo" y aumentar el énfasis en "las dimensiones afectivas de la experiencia para el cineasta" (párr. 5). Estaríamos con El telón de azúcar ante un documental de este tipo. Lo subjetivo y lo afectivo son las marcas más fuertes del filme. Es la experiencia de Camila y sus 
modos de hacerse presente en la película lo que nos interpela, por sobre cualquier tipo de cualidad referencial. Sus vivencias personales y las de sus seres más cercanos (aquellos que formaron parte, justamente, de sus años constitutivos) son las que el documental nos presenta. Las fotografías, los dibujos y los testimonios que se hilvanan sobre la base del recuerdo, ponen de relieve de modo permanente lo subjetivo, afectivo y autorreferencial sobre lo que se construye el relato.

Continuando con la cita de las reflexiones de Weinrichter, Piedras sostiene que, en el documental performativo, se pone en primer término el hecho de la comunicación, sacando el foco de atención de la discusión objetividad/veracidad característica del documental tradicional. De este modo "los enunciados performativos no serían verificables, a diferencia de los enunciados descriptivos" (párr. 5). La subjetividad se impone. "El director literalmente 'actúa', siendo una primera persona que se materializa en la escena, ya sea interviniendo con su propio cuerpo o a través de un narrador omnipresente" (párr. 5). Camila se inscribe en el documental de ambos modos. Con su propio cuerpo, a través de fotos de su infancia y a partir del mecanismo de filmar su reflejo en un espejo mientras realiza preguntas a su madre en su casa. Y a través de su voz como narradora omnipresente y realizando preguntas en off.

El formato de un documental como El telón de azúcar es además de autobiográfico y performativo, ensayístico. En este sentido, Paola Lagos Lobbé (2011) sostiene que “(e)l ensayo -por definición- más que aportarnos respuestas, nos formula preguntas; a través de la reflexión, nos interpela como espectadores convocándonos a someter al mundo a la prueba de la duda, a tomar distancia y a adoptar un punto de vista en la formulación de las ideas" (párr. 17). Algo de esto, que sin dudas forma parte de la propuesta del film, se materializa incluso en una reflexión en off que realiza la propia cineasta. En el registro de una marcha (de las muchas que se realizan ahora, según ella misma sostiene, y a las que las personas acuden por obligación o 
por inercia, por contraposición a las menos numerosas y más significativas de otros tiempos, a las que se asistía por convicción) Camila se pregunta si anteriormente no se cuestionaba al sistema por el confort que el mismo propiciaba y si el resquebrajamiento de ese bienestar no es el que tal vez permita la toma de distancia y adopción de un nuevo punto de vista. Agrega finalmente, sólo ahora me doy cuenta que si no seguí chocando con el sistema, fue porque me fui y me quedé con un recuerdo idílico de algo que quizás nunca fue. Lagos Lobbé plantea la existencia, en estos filmes, de una

voz en off que matiza, cuestiona, da cuenta de los estados de ánimo del autor y sus disquisiciones vitales, voz que no posee certezas y que, por lo tanto, difiere consustancialmente del comentario ilustrado, omnisciente, anónimo, de las autoritarias voces en off del documental expositivo, que certifican y autentifican pretendidas verdades universales y conocimientos absolutos. (párr. 17).

La voz de Camila, como acabamos de confirmar, retorna en múltiples ocasiones a lo largo del metraje, sin verdades absolutas sino plena de cuestionamientos y subjetividad, mucho más cargada de su historia que de la Historia.

Pablo Piedras considera que la profusión del uso de la primera persona en los documentales latinoamericanos en los años 2000 tiene que ver con "la imposibilidad del documental clásico de dar cuenta de una verdad histórica sobre los hechos traumáticos de la historia reciente" (párr. 13). Los documentales que mejor repercusión han tenido en el registro de las vicisitudes propias del Período Especial han sido filmes que escaparon a las pautas más clásicas del género ${ }^{8}$. El telón de azúcar es uno de ellos. Piedras continúa:

\footnotetext{
${ }^{8}$ El documental de mayor repercusión de las últimas décadas fue Suite Habana (Fernando Pérez, 2003). Proponiendo un lenguaje sumamente particular, que toma muchos elementos propios del cine de ficción, el film registra con extrema sensibilidad a unos personajes y a una ciudad atravesados por el Período Especial. Sobre el mismo se puede consultar un
} 
Resignificando la lectura del pasado a través de la propia subjetividad de los realizadores, el documental subjetivo encuentra verdades parciales, tentativas y provisorias, pero profundamente encarnadas y operativas para la construcción de una memoria cercana que transite de lo individual a lo colectivo, invirtiendo de esta forma la parábola del cine político militante de la década de los setenta. (párr. 13).

Este es el movimiento que realiza el documental de Guzmán Urzúa: sus verdades no son absolutas sino parciales, no son definitivas sino provisorias, pero sí profundamente encarnadas en una subjetividad. Una construcción desde lo individual que se extiende hacia lo colectivo. Ese cuestionamiento que Camila se hace respecto a sí misma, cuando escuchamos su voz en off sobre las imágenes de la marcha convocada con motivo del natalicio de José Martí, repercute hacia lo colectivo, se expande convirtiéndose en un cuestionamiento general.

En este sentido, y en comparación con la documentalística tradicional, Piedras plantea que la incorporación de la subjetividad y la primera persona en el documental "promueve la aparición de nuevos pactos comunicativos entre la obra y el espectador, a la vez que genera un giro epistemológico que se vislumbra en la ruptura de los sistemas explicativos tradiciones por medio de los cuales el documental clásico explicaba y daba cuenta de diversos fenómenos históricos, políticos y sociales" (párr. 28). De este modo, tanto Pablo Piedras como Ana Amado plantean una distinción entre los documentales de los años 2000 y los de la década del setenta. Se construye en los primeros un nuevo régimen de verdad, que en lugar de centrarse en afirmaciones políticas contundentes, como sucedía en los setenta, expone un discurso afectivo. Frente a las características colectivas y sociales del cine documental de los setenta, en el cine reciente se trabaja,

artículo de autoría propia titulado "Suite Habana, los sonidos del silencio" y publicado en el número 12 de la revista Cine Documental (http://revista.cinedocumental.com.ar/suitehabana-los-sonidos-del-silencio/). 
como hemos expresado, desde la individualidad. Ana Amado señala un pasaje representacional del relato épico al trágico.

Coincide en estas apreciaciones Esteban Dipaola al señalar que el estudio de los noventa no puede centrarse en el archivo o el documento.

Ese recurso de análisis usual en la sociología y afines para la comprensión de la década del setenta por ejemplo, pierde su eficacia para un pensamiento de los años noventa, porque, como venimos sosteniendo, no se trata de la potencialidad de exponer un relato sobre esa década, sino de entender a la propia década como un dispositivo que inaugura múltiples potenciales relatos y que los dispersa a todos abriendo sus constantes e indeterminados cruces y desviaciones. Entonces, los años noventa no se insertan en la lógica del archivo y el documento, sino en la pulsión narrativa de nuestras trayectorias actuales en tiempo presente. (Dipaola, 2012: 36, $37)$.

Los materiales de archivo y los documentos en El telón de azúcar son personales y subjetivos. En este sentido nos referimos a los dibujos y las fotografías escolares y familiares, pero también incluso al único fragmento de película que podría considerarse más clásicamente como "archivo documental" y que, de todos modos, la narración inscribe como sumamente íntimo. Se trata de un fragmento de Primer año (1972), documental de Patricio Guzmán, padre de Camila, sobre cuya imagen la voz en off de la cineasta inscribe el trazo de lo único y personal: mientras su padre registraba las imágenes de Fidel Castro y Salvador Allende en Chile su madre presenciaba el desfile y ella también, desde su panza, justo un mes antes de nacer. Hay en Guzmán Urzúa esa pulsión narrativa que busca sobre todo indagar sobre la actualidad comprendiéndola como un tiempo en el que otras temporalidades indefectiblemente se proyectan. 


\section{Palabras finales}

Los noventa en Cuba implican un quiebre drástico en el entramado social. La profunda crisis económica que debió enfrentar el país a partir del derrumbe de la Unión Soviética quedó grabada a fuego en la sociedad. Creemos que parte de lo que se produjo se puede explicar a partir de lo que Ulrich Beck (2006) llama individualización y que implica una disolución de formas sociales históricas, una pérdida de seguridades tradicionales y un nuevo tipo de cohesión social. Estos aspectos son apreciables a su vez en la producción cultural posterior al período, en el cine y, en particular, en el documental que se tomó como caso en el presente trabajo, El telón de azúcar (Camila Guzmán Urzúa, 2005). A su vez, resultan apreciables en esta producción y en la cinematografía cubana a nivel más amplio algunos conceptos que Esteban Dipaola (2012) pone en juego para caracterizar a diversas manifestaciones culturales argentinas del período: la fuga, la deriva, los traslados, el despojo, el desamparo y la idea de que no hay nada o mucho para hacer. Pero los noventa, al margen de ser retratados de este modo en la producción que los procede, aparecen de modo latente también desde otro lugar. Como plantea el autor, los noventa también y sobre todo se manifiestan como una pulsión que impulsa la necesidad y la búsqueda de una nueva mirada que no es necesariamente ni tan sólo una mirada sobre el pasado, sino más bien una mirada sobre la actualidad. Consideramos que esa pulsión es la que lleva a Guzmán Urzúa a realizar El telón de azúcar.

A partir de esa pulsión, el documental plantea también un nuevo régimen de verdad. A diferencia del documental tradicional, que ponía el foco sobre la objetividad, la veracidad, lo verificable, la certeza y el hincapié en la Historia, en el documental de características autobiográficas, performativas, ensayísticas, en primera persona, el foco pasa al hecho de la comunicación, la subjetividad, el cuestionamiento, lo individual, lo propio, el hincapié en las historias. Son estos aspectos los que constituyen un nuevo 
tipo de verdad que ya no es la Verdad sino una verdad. En este sentido, nos atrevimos a esbozar la posibilidad de pensar el régimen de verdad en $E l$ telón de azúcar en términos de Alain Badiou (2012), considerando al amor como procedimiento de verdad que se pone en juego en el film.

Lo fuertemente traumático de la historia reciente, como sostiene Pablo Piedras (2009), puede pensarse como lo que hace que la posibilidad primordial de encararlo sea desde la subjetividad de la primera persona. A su vez, coincidiendo con lo propuesto por Dipaola, creemos que los noventa son eso que nos pasó y no deja de pasarnos y, de ese modo, son constitutivos de nuestros esfuerzos de explicación del presente, por lo cual el archivo y el documento no son ya suficientes para comprender esa década conflictiva y fundante. Sobre todo porque lo que esa década provoca en nosotros es la necesidad y la pulsión de generar nuevas miradas que, desde allí, nos permitan comprendernos ahora y, desde este ahora, nos ayuden a comprender cómo eso que nos pasó se actualiza en cada uno de nuestros actos creativos.

\section{Referencias bibliográficas}

ÁLVAREZ ARCE, Mauricio (2006), La transformación del discurso oficial y la representación del Modelo político cubano en la década de los noventas, Seminario de tesis, México: Flacso.

AMADO, Ana (2009), La imagen justa. Cine argentino y política (19802007), Buenos Aires: Colihue.

BADIOU, Alain y TRUONG, Nicolas (2012), "Verdad del amor" en Elogio del amor, Buenos Aires: Paidós.

BECK, Ulrich (2006), “Individualización, institucionalización y estandarización de las condiciones de vida u de los modelos 
biográficos", en La sociedad del riesgo. Hacia una nueva modernidad, Barcelona: Ediciones Paidós Ibérica.

DEL RÍO, Joel (2011), “Fermentos genéricos en el cine joven del siglo XXI", en Notario, Luis Alberto y Paddington, Bruce, Explorando el cine caribeño, La Habana, Ediciones ICAIC, pp. 382-417.

DIPAOLA, Esteban (2012), Todo el resto. Estética y pulsión de los años '90, Buenos Aires: Pánico el pánico.

KLEPAK, Hal (2010), Raúl Castro, estratega de la defensa revolucionaria de Cuba, Buenos Aires: Capital Intelectual.

LAGOS LABBÉ, Paola (2011), "Ecografías del "Yo": documental autobiográfico y estrategias de (auto)representación de la subjetividad", en Comunicación y medios n. 24, Instituto de la Comunicación e Imagen, Universidad de Chile.

PIEDRAS, Pablo (2009), "El problema de la primera persona en el cine documental contemporáneo. Modos de representar lo autobiográfico en ciertos documentales latinoamericanos", ponencia presentada en las V Jornadas de Jóvenes Investigadores del Instituto Gino Germani, Buenos Aires, Facultad de Ciencias Sociales de la Universidad de Buenos Aires.

SELBIN, Eric (2012), "Un prolegómeno, una apología y una obertura”, en El poder del relato. Revolución, rebelión, resistencia, Buenos Aires: Interzona Editora. 